\title{
La Reichenau, un haut lieu de la médiévistique allemande
}

\section{Pierre Monnet}

\section{OpenEdition}

\section{Journals}

Édition électronique

URL : http://journals.openedition.org/ifha/8016

DOI : 10.4000/ifha. 8016

ISSN : 2198-8943

\section{Éditeur}

IFRA - Institut franco-allemand (sciences historiques et sociales)

\section{Édition imprimée}

Date de publication : 31 décembre 2014

ISSN : 2190-0078

\section{Référence électronique}

Pierre Monnet, "La Reichenau, un haut lieu de la médiévistique allemande », Revue de l'IFHA [En ligne], 6 | 2014, mis en ligne le 31 décembre 2014, consulté le 02 mai 2019. URL : http://

journals.openedition.org/ifha/8016 ; DOI : 10.4000/ifha.8016

Ce document a été généré automatiquement le 2 mai 2019.

(C)IFHA 


\title{
La Reichenau, un haut lieu de la médiévistique allemande
}

\author{
Pierre Monnet
}

1 Parmi les institutions qui fabriquent l'histoire médiévale en Allemagne figure le cercle bien connu dit de «la Reichenau». De son véritable nom «Konstanzer Arbeitskreis für mittelalterliche Geschichte», soit "Groupe de travail de Constance pour l'histoire médiévale ", cette institution fondée en 1951 regroupe de nombreux médiévistes allemands, a son siège à Constance, réunit deux fois l'an des rencontres sur l'île de la Reichenau, édite des actes de colloque et des volumes d'études publiés dans la collection «Vorträge und Forschungen » chez l'éditeur Thorbecke (Ostfildern, 78 titres à ce jour, http://www.thorbecke.de/vortraege-und-forschungen-c-310_138_244.html, complétés par 56 volumes hors-série et 13 volumes d'hommage).

2 Les deux rencontres annuelles, l'une au printemps et l'autre à l'automne, font également intervenir des médiévistes d'autres pays, et des français notamment. Les thématiques retenues couvrent tous les champs et toutes les périodes du Moyen Âge, et certains colloques ont constitué de véritables tournants épistémologiques ou méthodologiques, tels «L'espace public politique à la fin du Moyen Âge », «La famille dans la société du Moyen Âge ", "Formes et fonctions de la communication au Moyen Âge », "Construction et perception de l'espace à la fin du Moyen Âge », "La tolérance au Moyen Âge ", " Porteurs et instruments de la paix au Moyen Âge ", « Élire et élections au Moyen Âge », "Écriture et conscience de l'histoire au Moyen Âge », «L'État territorial au Moyen Âge ».

3 Assisté d'une commission scientifique rassemblant les 52 membres inscrits, le cercle est actuellement présidé par Claudia Zey, professeure à l'université de Zurich. Il comporte également deux sections régionales qui organisent aussi des rencontres scientifiques annuelles, celle de Hesse/Rhin moyen et celle de Suisse/Sud-Ouest.

Site institutionnel : http://wp.konstanzer-arbeitskreis.de/ 


\section{AUTEUR}

PIERRE MONNET

(EHESS), directeur de l'IFHA 